\section{Case Reports in Dermatology}

Case Rep Dermatol 2021;13:129-133

DOl: $10.1159 / 000512871$

Published online: February 18, 2021
(C) 2021 The Author(s)

Published by S. Karger AG, Basel www.karger.com/cde

This article is licensed under the Creative Commons Attribution-NonCommercial 4.0 International License (CC BY-NC) (http://www.karger.com/Services/OpenAccessLicense). Usage and distribution for commercial purposes requires written permission.

\title{
A Low-Grade Trichoblastic Carcinoma Treated with Mohs Micrographic Surgery
}

\author{
Annemiek Leeman ${ }^{a} \quad$ Erienne M.V. de Cubab Lies H. Jaspars ${ }^{c}$ \\ Koen D. Quint ${ }^{a}$ Roel E. Genders ${ }^{a}$ d \\ ${ }^{a}$ Department of Dermatology, Leiden University Medical Center, Leiden, The Netherlands; \\ bPathan, Rotterdam, The Netherlands; 'Department of Pathology, Amsterdam University \\ Medical Center, Amsterdam, The Netherlands; dDepartment of Dermatology, Roosevelt \\ Clinic, Leiden, The Netherlands
}

\section{Keywords}

Trichoblastoma $\cdot$ Trichoblastic carcinoma $\cdot$ Mohs micrographic surgery

\begin{abstract}
Trichoblastomas are rare dermal neoplasms usually found on the scalp and face. Histology shows a proliferation of small basaloid cells arranged in cords or fields surrounded by cellular stroma. Trichoblastomas are usually not aggressive, but trichoblastic carcinomas arising from preexisting trichoblastomas have been described and have been linked to basal cell carcinoma. We found a tumor with features of trichoblastoma with presence of Merkel cells, but with a deeply infiltrative growth pattern into the fat and muscle tissue, without significant architectural or cellular atypia. Tumors with similar growth patterns were previously described as deeply invasive trichoblastic neoplasms. It appears to be a new entity that has been described before but has not been fully characterized: low-grade trichoblastic carcinoma. This malignancy seems to show only locally aggressive growth. Radical excision was accomplished with Mohs micrographic surgery.




\section{Case Reports in Dermatology}

\begin{tabular}{l|l}
\hline DOI: $10.1159 / 000512871$ & (c) 2021 The Author(s). Published by S. Karger AG, Basel
\end{tabular} www.karger.com/cde

Leeman et al.: A Low-Grade Trichoblastic Carcinoma Treated with Mohs Micrographic Surgery

\section{Introduction}

Trichoblastoma is a rare dermal neoplasm constituted of follicular germinative cells. Histologically, proliferation of small basaloid cells arranged in cords or fields surrounded by cellular stroma are seen [1]. They are usually found on the scalp and face, involving the deep dermis and rarely subcutis. Trichoblastoma is usually not aggressive, but trichoblastic carcinomas arising from preexisting trichoblastomas have been described and have been linked to basal cell carcinoma [2].

\section{Case Report}

A 50-year-old woman was referred for a cosmetically disturbing bump on the chin (Fig. 1). It had been there for 10 years, slowly growing without giving any further complaints. She had no significant medical history, was on no medication, and reported over 10 pack-years of smoking.

Skin examination showed a 15-mm smooth, elevated nodule with telangiectasias but no significant shine on the left side of the chin. The border of the neoplasm was sampled with a 3-mm punch biopsy under the suspicion of basal cell carcinoma. Pathological examination resulted in a preferred diagnosis of trichoblastoma. However, in view of the high clinical suspicion of basal cell carcinoma it was decided to excise the lesion in toto by Mohs micrographic surgery.

\section{Microscopic Examination}

Initial pathological examination of the excision specimen showed a tumor with paracentral basal proliferation without a clear connection to the epidermis. There were slightly atypical basaloid fields showing minimal cytonuclear atypia surrounded by fibrous stroma and some scattered mitotic figures and local lumen formation. The tumor showed a diffuse, deeply invasive growth pattern in which tumor fields were observed between fat and striated muscle tissue, remarkably enough retaining both tissue components and organoid architecture (Fig. 2). There was no perineural or vaso-invasive growth.

Additional immunohistochemistry showed diffuse positivity for BerEP4 with some tumor fields showing diffuse keratin (CK) 7 positivity. CK20 staining showed some fields with presence of Merkel cells. The tumor cells were mostly androgen receptor negative, which together with the CK20 stain correlated with a trichoblastic tumor. Considering the invasive growth pattern of the tumor, the preferred diagnosis of low-grade trichoblastic carcinoma was made.

\section{Discussion}

This tumor showed features of trichoblastoma with its characteristic biphasic structure of tumor fields with organoid composition of stromal and epithelial components. In addition, the presence of Merkel cells highlighted in the CK20 stain, which distinguishes trichoblastoma from basal cell carcinoma, is in line with this diagnosis. The tumor showed diffuse, deeply infiltrative growth into the fat and muscle tissue without significant architectural or cellular atypia, mostly fitting with a locally aggressive growth pattern. In high-grade trichoblastic carcinoma, the epithelium is degenerated and develops into an invasive tumor overgrowing the

\section{Karger'=}




\section{Case Reports in Dermatology}

\begin{tabular}{l|l}
\hline Case Rep Dermatol 2021;13:129-133 \\
\hline DOI: 10.1159/000512871 & $\begin{array}{l}\text { C 2021 The Author(s). Published by S. Karger AG, Basel } \\
\text { www.karger.com/cde }\end{array}$ \\
\hline
\end{tabular}

Leeman et al.: A Low-Grade Trichoblastic Carcinoma Treated with Mohs Micrographic Surgery

stromal component, either with preservation of some follicular characteristics or as an undifferentiated carcinoma. In such a lesion, extensive comedo-like necrosis, high mitotic activity, and lack of continuity with the epidermis may be seen adjacent to a benign trichoblastoma [3].

Tumors with similar growth patterns were previously described by Rofagha et al. [4] and were called "deeply invasive trichoblastic neoplasms" and Kazakov et al. [5] also showed a case with similar histology, which was referred to as a rare biphasic follicular neoplasm resembling trichoblastoma but with features of malignancy by virtue of infiltrative growth.

It appears that the case described here belongs to a new entity that has been described before but has not yet been fully characterized: low-grade trichoblastic carcinoma. It concerns a malignancy that seems to only show locally aggressive growth; metastases have not been reported. However, the number of cases is very limited and long-term follow-up is not well established [6].

Because of the diffuse and infiltrative growth pattern of the tumor, radical excision was recommended. Our patient was treated with Mohs micrographic surgery.

\section{Acknowledgements}

The authors thank all laboratory and clinical personnel for their technical and clinical support.

\section{Statement of Ethics}

This case report was conducted ethically in accordance with the World Medical Association Declaration of Helsinki. The patient provided written informed consent to perform all necessary investigations, take clinical photographs, and use them for research purposes and publication anonymously.

\section{Conflict of Interest Statement}

The authors report no conflict of interest.

\section{Funding Sources}

The authors did not receive any funding for this work.

\section{Author Contributions}

A.L. wrote the manuscript with support of all authors. E.M.V.d.C, L.H.J., and K.D.Q. did the histological reviewing and provided the histology images. R.E.G. was the treating physician, conceived the original idea, and supervised the project.

\section{Karger'"}




\section{Case Reports in Dermatology}

\section{References}

1 Patterson JW. Weedon's Skin Pathology. Elsevier, 2017.

2 Tebcherani AJ, de Andrade HF Jr, Sotto MN. Diagnostic utility of immunohistochemistry in distinguishing trichoepithelioma and basal cell carcinoma: evaluation using tissue microarray samples. Mod Pathol. 2012 Oct;25(10):1345-53.

3 Kwock JT, Casady M, Handfield C, MacLeod AS, Pavlis MB. A trichogenic tumor with aggressive features initially diagnosed as basal cell carcinoma. Dermatol Online J. 2018 Sep;24(9):13030/qt1fn5226f.

4 Rofagha R, Usmani AS, Vadmal M, Hessel AB, Pellegrini AE. Trichoblastic carcinoma: a report of two cases of a deeply infiltrative trichoblastic neoplasm. Dermatol Surg. 2001 Jul;27(7):663-6.

5 Kazakov DV, McKee PH, Michal M, Kacerovska D. Cutaneous Adnexal Tumors. Wolters Kluwer Health/Lippincott Williams \& Wilkins, 2012.

6 Hua C, Velter C, Osio A, Lebbe C, Basset-Seguin N, Cribier B, et al. Locally Aggressive Trichoblastic Tumours (Low-grade Trichoblastic Carcinomas): Clinicopathological Analysis and Follow-up. Acta Derm Venereol. 2018 Jan;98(1):126-7.

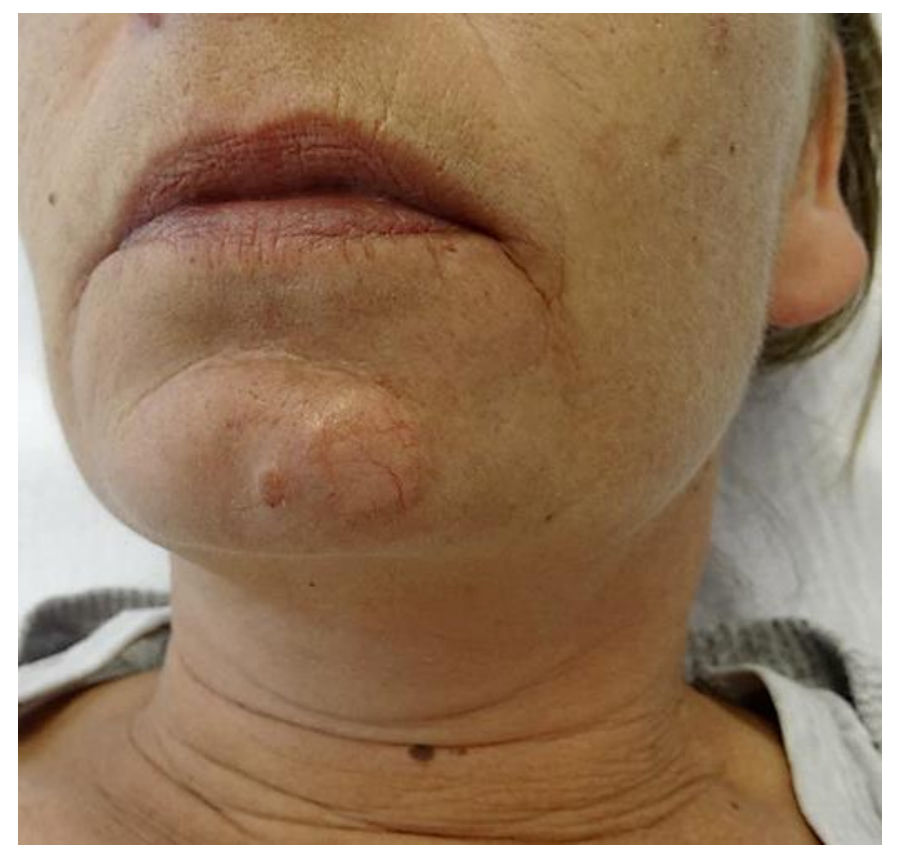

Fig. 1. 50-year-old female with a 15-mm nodule on the left side of the chin. This image shows a smooth, elevated nodule with telangiectasias. 


\section{Case Reports in Dermatology}

\begin{tabular}{l|l}
\hline Case Rep Dermatol 2021:13:129-133 \\
\hline DOI: 10.1159/000512871 & $\begin{array}{l}\text { @ } 2021 \text { The Author(s). Published by S. Karger AG, Basel } \\
\text { www.karger.com/cde }\end{array}$ \\
\hline
\end{tabular}

Leeman et al.: A Low-Grade Trichoblastic Carcinoma Treated with Mohs Micrographic Surgery

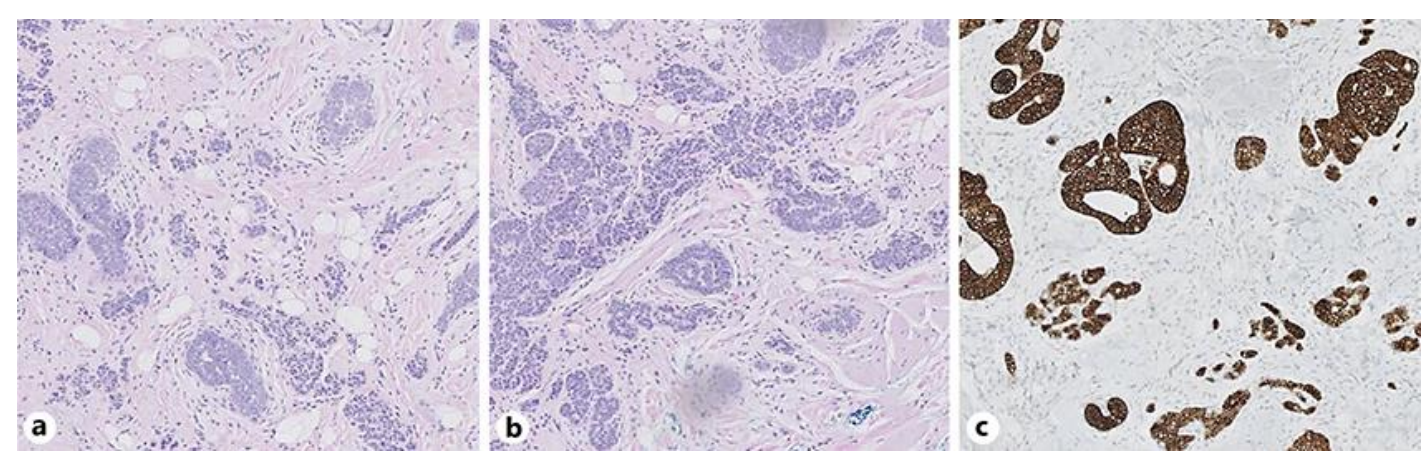

Fig. 2. Sections showing cellular atypia (a) and muscle invasion (b) on H/E staining and an epidermal component showing BErEp4 (c). 